\title{
Beta-cell mitochondria in the regulation of insulin secretion: a new culprit in Type II diabetes
}

\section{B. Wollheim}

Division of Clinical Biochemistry and Experimental Diabetology, Department of Internal Medicine, University Medical Centre, Geneva, Switzerland

\section{Abstract}

Insulin is stored in secretory granules in the beta-cell and is secreted by exocytosis. This process is precisely controlled to achieve blood glucose homeostasis. Many forms of diabetes mellitus display impaired glucose-induced insulin secretion. This has been shown to be the primary cause of the disease in the various forms of maturity-onset diabetes of the young (MODY) and has also been implicated in adult-onset Type II (non-insulin-dependent) diabetes mellitus. Glucose generates ATP and other metabolic coupling factors in the beta-cell mitochondria. By plasma membrane depolarisation ATP promotes $\mathrm{Ca}^{2+}$ influx, which raises cytosolic $\mathrm{Ca}^{2+}$ and triggers insulin exocytosis. Through hyperpolarisation of the mitochondrial membrane glucose also increases the $\mathrm{Ca}^{2+}$ concentration in the mitochondrial matrix activating $\mathrm{Ca}^{2+}$ sensitive dehydrogenases in the tricarboxylic acid cycle. The resulting generation of glutamate participates in $\mathrm{Ca}^{2+}$-stimulated exocytosis. Mitochondrial DNA (mtDNA) encodes some of the polypeptides of the respiratory chain enzyme complexes. Mutations in mtDNA lead to maternally inherited diabetes mellitus characterised by impaired insulin secretion. The impact of altered mtDNA on insulin secretion has been shown in mtDNA-deficient beta-cell lines which have lost glucose-stimulated insulin secretion but retain a $\mathrm{Ca}^{2+}$-induced insulin secretion. A cellular model of MODY3 expressing dominant-negative hepatocyte nuclear factor- $1 \alpha$ (HNF-1 $\alpha$ ) also displayed deletion of glucose-induced but not $\mathrm{Ca}^{2+}$-induced insulin secretion. Reduced mitochondrial metabolism explains this secretory pattern. Thus, genetically manipulated beta-cell lines are essential tools in the investigation of the molecular basis of beta-cell dysfunction in diabetes and should explain the role of other transcription factors in the disease. [Diabetologia (2000) 43: 265-277]

Keywords Beta-cell dysfunction, mitochondrial metabolism, mitochondrial DNA, exocytosis, ATP, cytosolic $\mathrm{Ca}^{2+}$, mitochondrial $\mathrm{Ca}^{2+}, \varrho^{0}$ cells, HNF-1 $\alpha$, MODY.
In previous lectures, Claude Bernard's many scientific contributions have been highlighted. Among others he suggested in 1850 that the liver stores glucose

Corresponding author: Professor C.B. Wollheim, Division of Clinical Biochemistry and Experimental Diabetology, Department of Internal Medicine, University Medical Centre, 1211 Geneva 4, Switzerland

30th Claude Bernard Lecture given during the 34th Annual Meeting of the EASD, Barcelona, September 1998 and dedicated to the memory of my late mentor, Professor Albert Renold, who gave the 5th Claude Bernard lecture in 1973 [1]

Abbreviations: TCA, Tricarboxylic acid; $\mathrm{K}_{\mathrm{ATP}}$, ATP-sensitive $\mathrm{K}^{+} ; \mathrm{HNF}-4 \alpha$, hepatocyte nuclear factor $4 \alpha$. and 7 years later, in 1857, he finally isolated glycogen [2]. Before that, in 1849, Claude Bernard reported his "Piqûre sucrée" to the Société de Biologie, Paris [3]. In analogy to his experiments in which stimulation of the fifth cranial nerve caused saliva secretion, he assumed that stimulation of the vagus nerve would elicit glucose secretion from the liver. In unanaesthetised rabbits and dogs, the pricking of the bottom of the fourth ventricle resulted in pronounced hyperglycaemia and glucosuria within $20 \mathrm{~min}$. The "diabetes" was transient and disappeared after a few hours. He later showed that this effect was mediated, not by the vagus, but by sympathetic nerves. His discovery of glycogen made Claude Bernard the true father of 


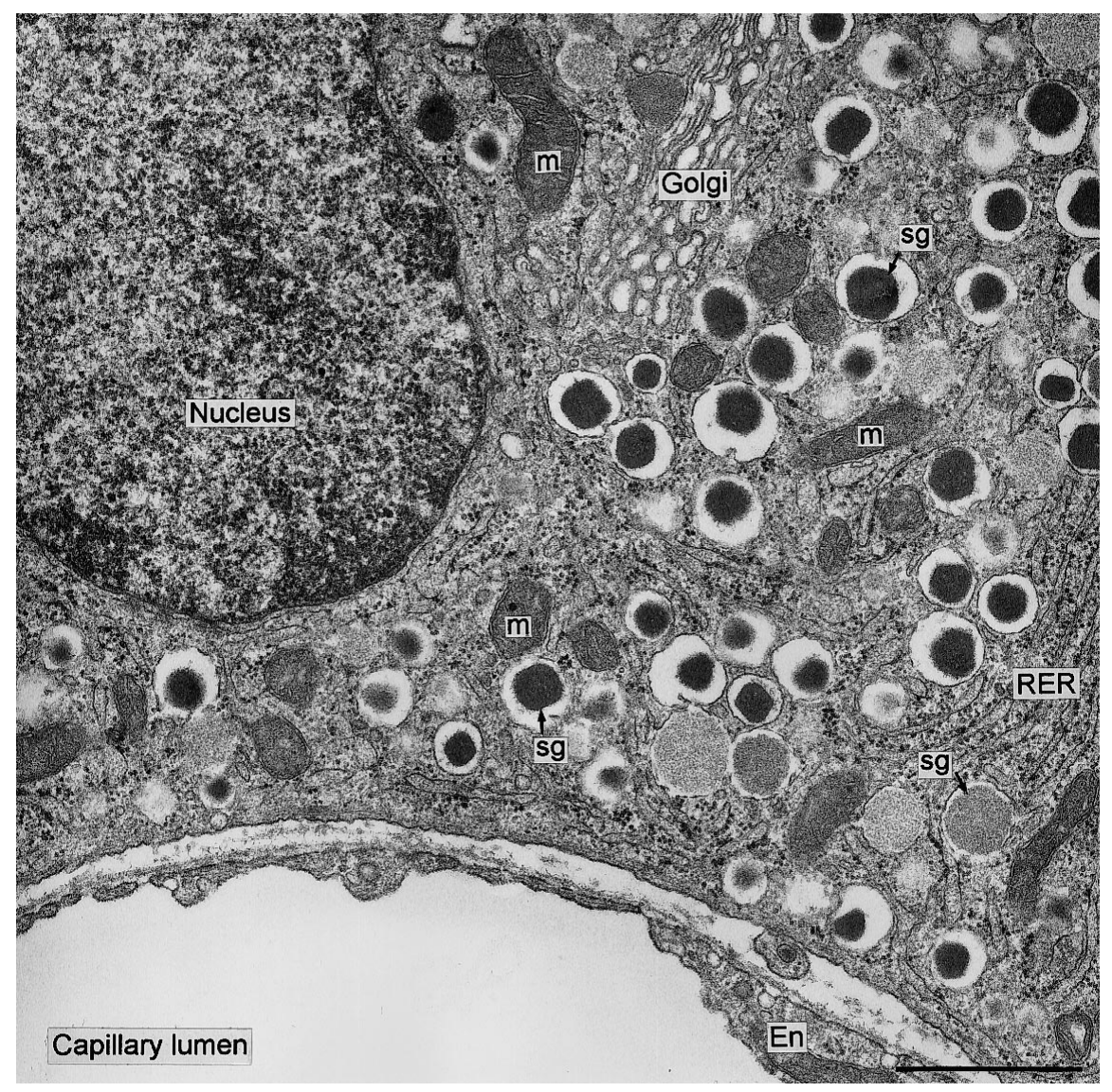

Fig. 1. Field of a beta cell in a thin section for electron microscopy showing the main intracellular membrane compartments: rough endoplasmic reticulum (RER), Golgi complex, insulincontaining secretory granules $(\mathrm{sg})$ and mitochondria $(\mathrm{m})$. Also visible is a part of an endothelial cell delimiting a capillary lumen (En). Normoglycaemic rat. The bar represents $1 \mu \mathrm{m}$. Unpublished document by L. Orci

intermediary metabolism. He considered the liver to be an organ of internal secretion, a concept nowadays reserved for endocrine function such as insulin secretion from the beta cell.

Figure 1 illustrates the ultrastructure of the beta cell with its main intracellular organelles. Insulin is synthesised in the endoplasmic reticulum and transported to the Golgi complex from which the insulincontaining secretory granules are formed by budding. Only a small proportion of the stored insulin is secreted into the islet capillaries during stimulation as indicated in a striking high magnification electron micrograph showing part of a beta cell with two secretory granules (Fig. 2). One has just fused with the plasma membrane and the granule core containing insulin in crystalline form is being washed out into the extracellular capillary space [4]. This process is referred to as exocytosis and is under intense study [5-9]. Figure 3 shows, in addition to secretory granules, beta-cell mitochondria which are the focus of this lecture. The outer and inner membranes of the mitochondria can be distinguished, as well as the inner membrane invaginations called cristae. The enzyme complexes of the respiratory (electron transport) chain are located on these cristae [10].

\section{Impaired insulin secretion in Type II diabetes mellitus}

A brief discussion of impaired glucose-induced insulin secretion in Type II diabetes sets the stage for this review. It is well established that the first phase of insulin secretion is impaired both in patients in a prediabetic state and after manifestation of Type II diabetes $[11,12]$. Such investigations were, however, generally done during i.v. glucose tolerance tests or more prolonged glucose infusions. These approaches give an inaccurate assessment of the second phase insulin release because of hyperglycaemia later in the test due to reduced initial insulin secretion [12]. When mildly Type II diabetic patients, treated by diet alone, were subjected to hyperglycaemic clamp, both phases of insulin secretion were considerably inhibited (Fig. 4) [13]. This was seen at glucose concentrations of 7.5, 10 and $15 \mathrm{mmol} / \mathrm{l}$. Both insulin secretion and tissue sensitivity to insulin are now known to be genetically controlled.

Accordingly, beta-cell dysfunction, as well as insulin resistance, have been proposed as primary causes 


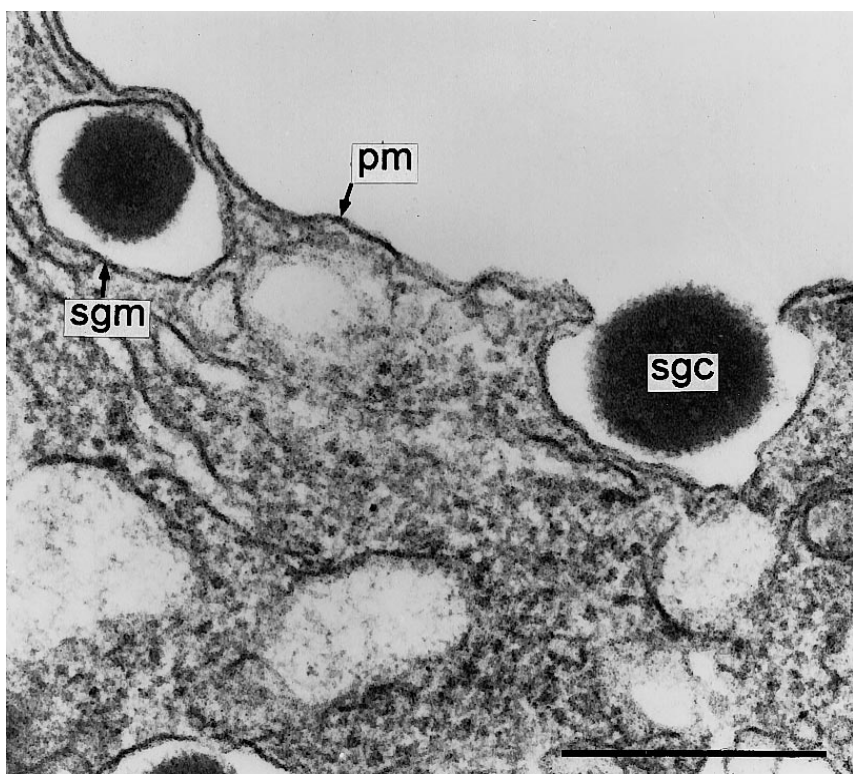

Fig. 2. Detail of the periphery of a beta cell showing an insulincontaining secretory granule in the process of exocytosis. The secretory granule membrane (sgm) and plasma membrane $(\mathrm{pm})$ are separate in the granule to the left but fused in the granule to the right, exposing the secretory granule core (sgc) to the extracellular space. Normoglycaemic rat. The bar represents $0.5 \mu \mathrm{m}$. Reprinted with permission from L. Orci [4]

of Type II diabetes [14, 15]. Hyperglycaemic clamp experiments in first-degree relatives of Type II diabetic patients showed normal glucose tolerance but there was a clear $25 \%$ reduction in both phases of insulin secretion (Fig.5). This multicentre study con-

Fig. 3. Detail of the beta-cell cytoplasm showing insulin-containing secretory granules $(\mathrm{sg})$ and mitochondria $(\mathrm{m})$. The mitochondrial outer and inner membranes are visible, the inner membrane folded into mitochondrial cristae. Normoglycaemic rat. The bar represents $0.5 \mu \mathrm{m}$. Unpublished document by L. Orci
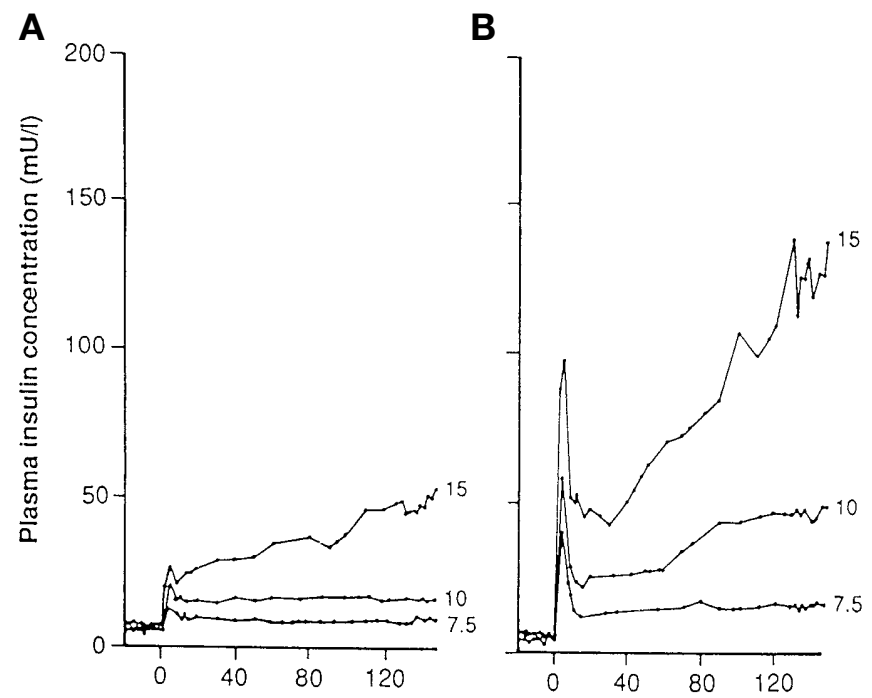

Fig. 4A, B. Plasma insulin concentrations during hyperglycaemic clamp studies at plasma glucose 7.5, 10 and $15 \mathrm{mmol} / \mathrm{l}$. A Diet-treated Type II diabetic patients. B Control subjects. Modified and reprinted with permission from Hosker et al. [13]

cluded that, in the group with a first-degree relative with Type II diabetes, impaired insulin secretion was about four to seven times more common than insulin resistance [16]. These results concur with other assessments of beta-cell function in similar cohorts and encourage further research into the mechanism of insulin secretion [14].

\section{Consensus model for the mechanism of insulin secretion}

The beta-cell is poised to sense glucose to accomplish the moment-to-moment adaptation of insulin secretion to blood glucose fluctuations. This is made possible through particular expression profiles of carbohydrate transporters and enzymes $[17,18]$ in the beta-

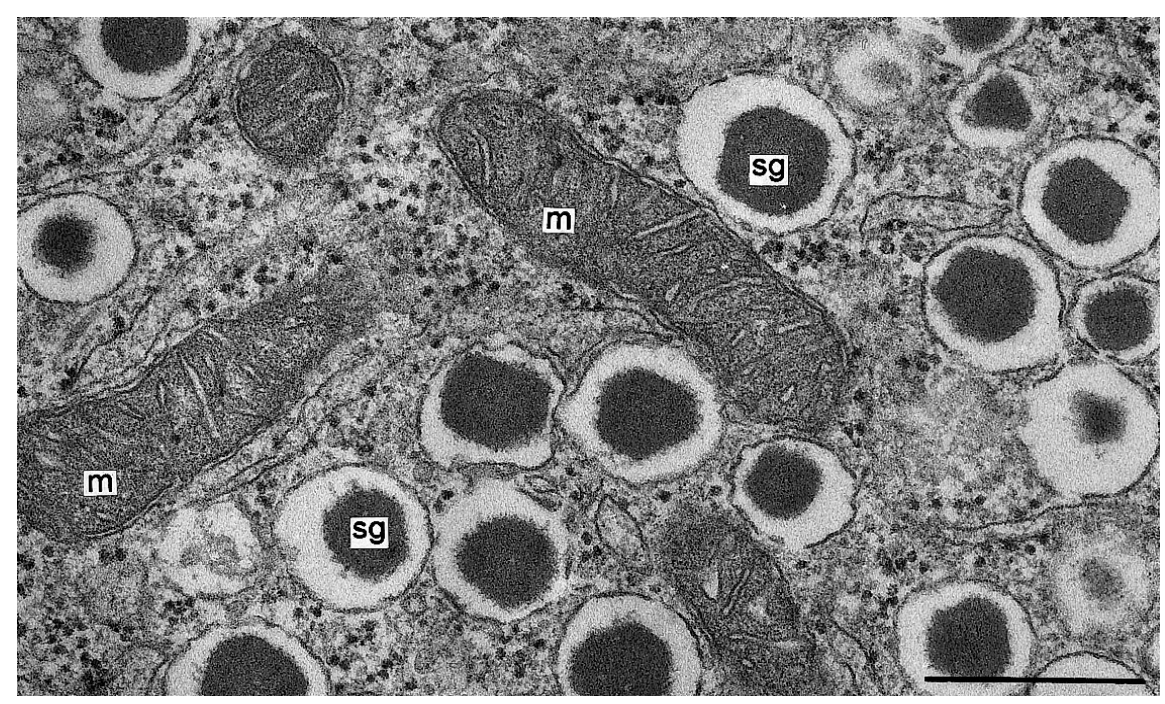



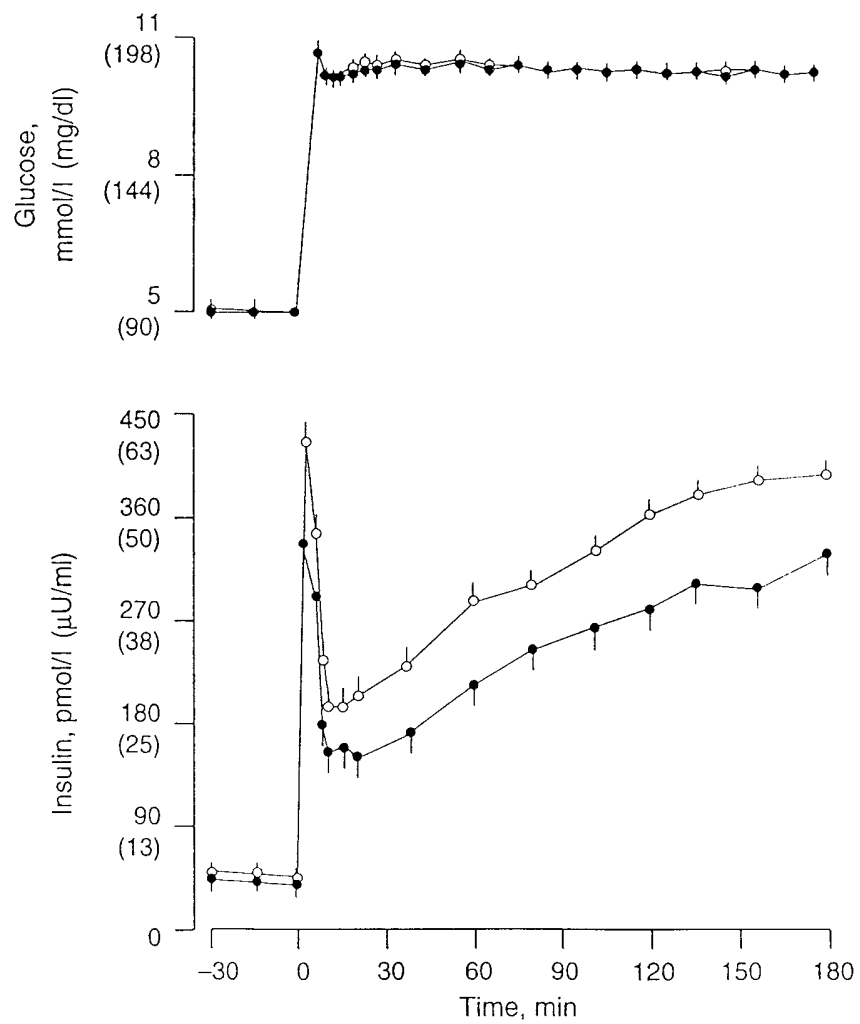

Fig. 5. Plasma glucose and insulin concentrations during hyperglycaemic clamp studies in first-degree relatives of patients with Type II diabetes $(\bullet, n=50)$ and control subjects $(\bigcirc$, $n=50)$. Means \pm SEM. Reprinted with permission from Pimenta et al. [16]

cell (Fig. 6). Three main molecular characteristics of glucose metabolism of the beta cell are of importance. Firstly, in beta cells like in hepatocytes, glucose equilibrates across the plasma membrane because both cell types express the high capacity, low affinity glucose transporter GLUT 2 [17]. In human beta cells, GLUT 2 is only moderately expressed and GLUT 1 dominates [19]. Secondly, glucose phosphorylation to glucose-6-phosphate is catalysed by high $\mathrm{K}_{\mathrm{M}}$ hexokinase IV called glucokinase (GK) which constitutes the flux determining step for glycolysis [17-20]. This enzyme was early proposed to be the "glucose sensor" [18] and it is now known that mutations in glucokinase underlie the impaired insulin secretion in MODY2 patients [21]. Thirdly, pyruvate generated by glycolysis is channelled to the mitochondria. Indeed, more than $90 \%$ of glucose carbons entering the beta cell are converted to $\mathrm{CO}_{2}$ in the mitochondria [22]. In addition, the beta cell has extremely low concentrations of lactate dehydrogenase $(\mathrm{LDH})$, the enzyme catalysing the conversion of pyruvate to lactate [22-24]. Furthermore, monocarboxylate transporter activity in the plasma membrane is low, which explains why pyruvate and lactate are not insulin secretagogues in native beta cells [23, 24]. Pyruvate, which enters the mitochondria, provides

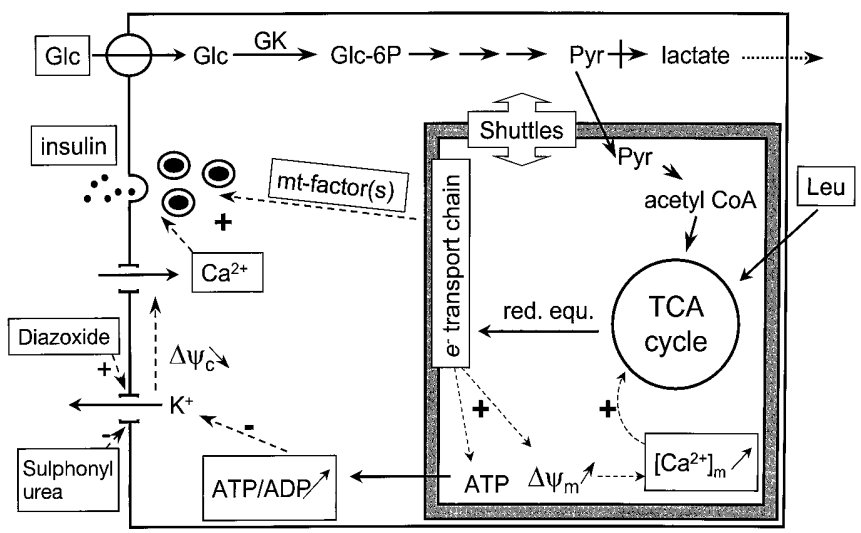

Fig. 6. Metabolism-secretion coupling in the beta cell. Glucose (Glc) is phosphorylated by glucokinase (GK). Glucose 6-phosphate (Glc-6P) is converted to pyruvate (Pyr) through glycolysis and is transported into the mitochondria to provide substrates to the tricarboxylic acid (TCA) cycle. The generated electrons are transferred to the respiratory chain (e-transport) which can also be directly stimulated by redox shuttles. Hyperpolarisation of the mitochondrial membrane potential $\left(\Delta \psi_{\mathrm{m}}\right)$ increases in $\left[\mathrm{Ca}^{2+}\right]_{\mathrm{m}}$. The ATP-sensitive $\mathrm{K}^{+}$channels are closed through metabolism. They are directly controlled by sulphonylureas and diazoxide. Their closure depolarises the plasma membrane potential $(\Delta \psi)$. The voltage-gated $\mathrm{Ca}^{2+}$ entry raises cytosolic $\mathrm{Ca}^{2+}$ and triggers insulin exocytosis. $\mathrm{Leu}=$ Leucine

substrate to the Krebs or tricarboxylic acid (TCA) cycle. This generates ATP and other mitochondrial factors, which promote insulin secretion $[17,18,22,25$, 26]. Substrate shuttles across the inner mitochondrial membrane also participate in the generation of mitochondrial signals by glucose $[17,27]$.

How, then, is glucose metabolism coupled to insulin secretion? The universal intracellular second messenger $\mathrm{Ca}^{2+}$ [28] is the crucial trigger for the exocytosis of insulin [5]. The concentration of ionised $\mathrm{Ca}^{2+}$ in the cytosol is raised by glucose in the following way. The increased TCA cycle activity leads to the production of reducing equivalents NADH and the reduced form of flavin adenine dinucleotide $\left(\mathrm{FADH}_{2}\right)$ in the mitochondrial matrix [29-31]. Thereby electrons are transferred to the electron transport chain which also receives electrons from the glycerol phosphate shuttle $[17,27]$. This has two consequences. Firstly, ATP is generated and transferred to the cytoplasm [25]. Secondly, the membrane potential across the inner mitochondrial membrane $\left(\Delta \psi_{\mathrm{m}}\right)$ is hyperpolarised, becoming more negative inside [26, 30, 32]. The cytosolic ATP, or rather the ATP:ADP ratio increases [18, 33], causing closure of ATP-sensitive $\mathrm{K}^{+}\left(\mathrm{K}_{\mathrm{ATP}}\right)$ channels. This was first shown in 1984 in excised beta-cell plasma membrane patches [34] and in glucose-stimulated intact cells [35]. Closure of $\mathrm{K}_{\mathrm{ATP}}$ channels depolarises the plasma membrane potential and causes typical electrical activity first observed 30 years ago [36]. The depolarisation evokes the opening of voltage-sensi- 
tive $\mathrm{Ca}^{2+}$ channels, which are mainly of L-type $[37,38]$ and $\mathrm{Ca}^{2+}$ enters the cell along its electrochemical gradient. In the presence of ATP, $\mathrm{Ca}^{2+}$ stimulates exocytosis of insulin granules [5,39]. The $\mathrm{Ca}^{2+}$ is, however, not only required for exocytosis but also seems to act as a messenger molecule inside the mitochondria, as first suggested for heart and liver cells [40]. This, as discussed below, occurs by mitochondrial membrane potential-driven $\mathrm{Ca}^{2+}$ entry and activation of the TCA cycle. It should be noted that, in contrast to glucose, the amino acid leucine, a physiological insulin secretagogue, is not transformed in the cytoplasm but directly enters the mitochondria. The subsequent generation of acetyl CoA stimulates the TCA cycle [41]. Consequently, the same down-stream effects as seen with glucose are set in motion. Leucine can thus be used to probe for defects in the metabolic pathway of glucose that precede the TCA cycle. Unfortunately, few clinical studies in diabetic patients have been done with leucine [42]. Instead, arginine is frequently used [12]. Arginine is only weakly metabolised by beta cells. The cationic amino acid depolarises the membrane potential following its accumulation in the beta cell, resulting in an increase in cytosolic $\mathrm{Ca}^{2+}$ [43]. Finally, sulphonylureas bind to the sulphonylurea receptor (SUR), a component of the ATP-sensitive $\mathrm{K}^{+}$channels, thereby promoting their closure and membrane depolarisation. The sulphonylurea analogue diazoxide has the opposite effect, causing channel opening and hyperpolarisation (Fig. 6) [44].

From the model to some illustrations of the model. Primary islet preparations have been extremely valuable models for biochemical studies. The laboratories of B.Hellman [45]. W. Malaisse [46] and F. Matschinsky [18], as well as many others have advanced our knowledge of stimulus-secretion coupling in the beta cell.

Over the last two decades permanent beta cell lines have proved to be essential for such studies as they can be genetically manipulated with great ease. We use a highly differentiated rat insulinoma cell line, INS-1, which was established in our laboratory [47]. These cells respond to an increase in the glucose concentration from 2.8 to $10 \mathrm{mmol} / \mathrm{l}$ with a biphasic insulin secretion (Fig.7) [47, 48]. For assessment of signal transduction, the cells were stably transfected with proteins permitting the monitoring of intracellular messengers. Using luciferase-expressing cells, P. Maechler showed that glucose increases cytoplasmic ATP in living cells [25]. This precedes the rise in cytosolic $\mathrm{Ca}^{2+}$ measured with the $\mathrm{Ca}^{2+}$-sensitive photoprotein aequorin. The biphasic increase in cytosolic $\mathrm{Ca}^{2+}$ is associated with a biphasic increase in the $\mathrm{Ca}^{2+}$ concentration inside the mitochondria $[48,49]$. Leucine, like glucose, raises the cytosolic and mitochondrial $\mathrm{Ca}^{2+}$ concentrations [49]. The cytosolic $\mathrm{Ca}^{2+}$ rise, together with the coupling factors of mitochondrial origin [32], evoke insulin secretion (Fig. 7).

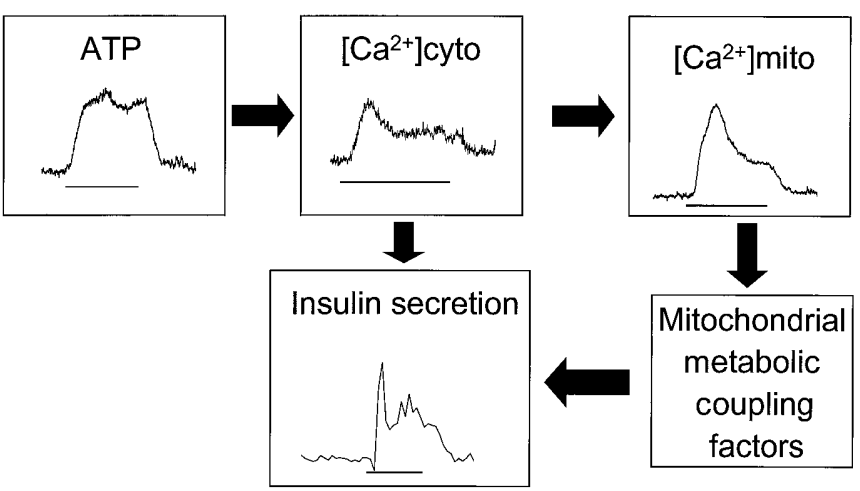

Fig. 7. The increases in cytosolic ATP, cytosolic $\mathrm{Ca}^{2+}$, mitochondrial $\mathrm{Ca}^{2+}$ and the generation of other coupling factors all contribute to biphasic glucose-stimulated insulin secretion

\section{$\mathrm{Ca}^{2+}$ activation of mitochondrial metabolism}

Is the rise in mitochondrial $\mathrm{Ca}^{2+}$ involved in signal generation? It was first shown by Jean-Claude Henquin [50, 51] and Toru Aizawa [52] and their collaborators that glucose could stimulate insulin secretion in a $\mathrm{K}_{\mathrm{ATP}}$-channel independent manner. In a now widely used experimental paradigm, diazoxide was added to inhibit the closure of $\mathrm{K}_{\mathrm{ATP}}$-channels by glucose (Fig. 6). This agent eliminates glucose-induced electrical activity, the rise in cytosolic $\mathrm{Ca}^{2+}$ and insulin release. Instead, the plasma membrane potential $(\Delta \psi)$ is depolarised by $\mathrm{K}^{+}$causing an increase in cytosolic $\mathrm{Ca}^{2+}$ to permissive concentrations. Despite the presence of diazoxide, the addition of stimulatory glucose concentrations promotes insulin secretion, resembling the slowly increasing second phase of secretion (Fig. 8) [50, 51].

What is the mechanism underlying the $\mathrm{K}_{\mathrm{ATP}}$-channel independent stimulation of insulin release? We hypothesised that a permissive increased cytosolic $\mathrm{Ca}^{2+}$ is required for activation of $\mathrm{Ca}^{2+}$-sensitive enzymes in the mitochondrial matrix. These enzymes are pyruvate dehydrogenase (PDH) which catalyses the conversion of pyruvate to acetyl CoA, the two TCA cycle enzymes, NAD-isocitrate dehydrogenase which generates $\alpha$-ketoglutarate and $\alpha$-ketoglutarate dehydrogenase producing succinyl CoA [40, 49, 53-56]. To show the role of $\mathrm{Ca}^{2+}$ in mitochondrial activation, we used the TCA cycle intermediate succinate which enters the cycle at the succinate dehydrogenase step (Fig.9). The latter enzyme links the TCA cycle and the respiratory chain, of which it constitutes complex II [10]. Succinate, in contrast to its methyl derivatives, does not enter intact beta cells and therefore permeabilised cells were used. Native beta cells or INS-1 cells were permeabilised with Staphylococcus aureus $\alpha$-toxin [32]. The $\alpha$-toxin makes small holes in the plasma membrane but leaves the organellar membranes intact. This allows the clamping of the cytosolic concentrations of ions and nucleotides such as $\mathrm{Ca}^{2+}$ and ATP 

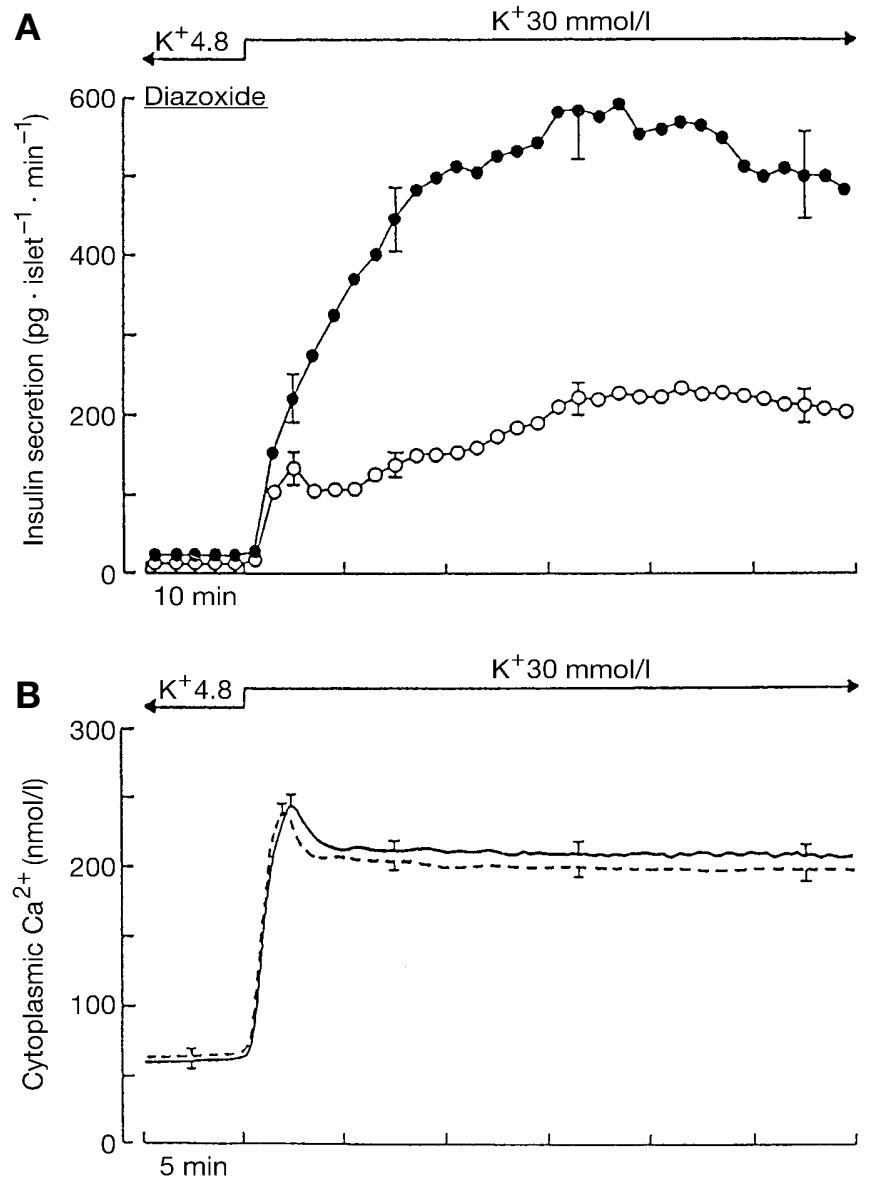

Fig.8 A, B. Effects of high glucose (G20 mmol/l) on insulin secretion $(\mathbf{A})$ at permissive cytosolic $\mathrm{Ca}^{2+}(\mathbf{B})$. Cytosolic $\mathrm{Ca}^{2+}$ was increased by the addition of $\mathrm{K}^{+}(30 \mathrm{mmol} / \mathrm{l})$ but was not changed by high glucose as diazoxide $(250 \mu \mathrm{mol} / \mathrm{l})$ was present throughout. The stimulation of insulin secretion $(\mathbf{A})$ is thus independent of the activity of ATP-sensitive $\mathrm{K}^{+}$channels under these conditions. A $\bullet, 20 \mathrm{mmol} / 1$ glucose; $0.6 \mathrm{mmol} / 1$ glucose. B —, $20 \mathrm{mmol} / \mathrm{l}$ glucose; ---, $6 \mathrm{mmol} / \mathrm{l}$ glucose. Reprinted with permission from Henquin et al. [51]

whereas the pores do not allow passage of proteins (Fig. 10). At the permissive $\mathrm{Ca}^{2+}$ concentration of $500 \mathrm{nmol} / \mathrm{l}$ succinate metabolism was increased fourfold compared with $100 \mathrm{nmol} / 1 \mathrm{Ca}^{2+}[56]$, the resting intracellular $\mathrm{Ca}^{2+}$ concentration of the beta cell [5]. This was measured as ${ }^{14} \mathrm{CO}_{2}$ production from $\left[{ }^{14} \mathrm{C}\right]$-labelled succinate which reflects the activity of the two $\mathrm{Ca}^{2+}$-sensitive TCA cycle enzymes (Fig. 9). Similar results have been published previously [55] for the activation of pyruvate dehydrogenase by $\mathrm{Ca}^{2+}$ in permeabolised HIT-T15 cells, a hamster beta-cell line.

\section{Mitochondrial activation directly stimulates insulin exocytosis}

Is the increased metabolism of succinate accompanied by stimulation of insulin secretion? In the permeabilised INS-1 cells, succinate hyperpolarises the

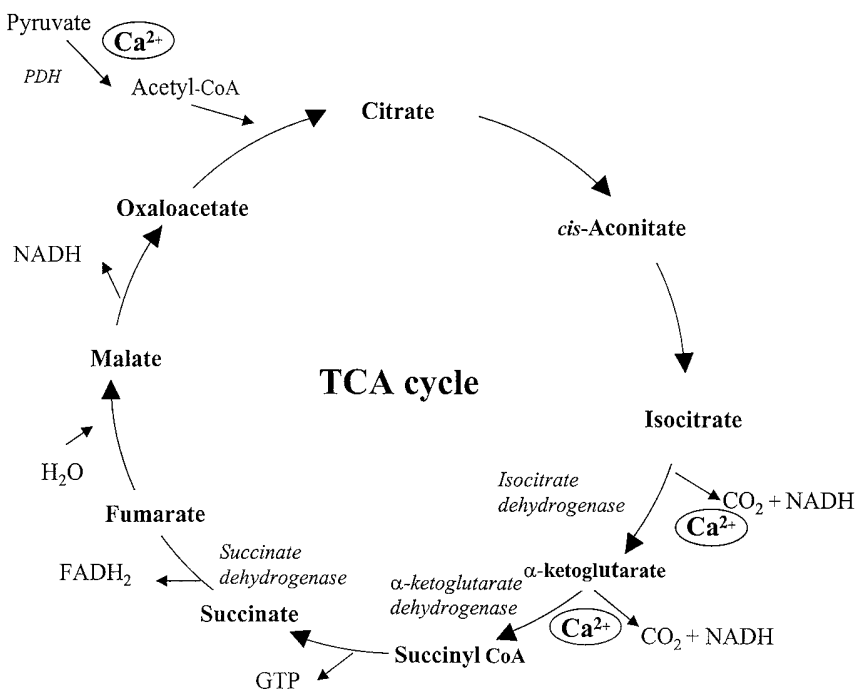

Fig.9. Schematic representation of the tricarboxylic acid (TCA) cycle. Pyruvate dehydrogenase (PDH), preceding the TCA cycle, as well as FAD isocitrate dehydrogenase and $\alpha$-ketoglutarate dehydrogenase are activated by $\mathrm{Ca}^{2+}$. The latter two enzymes generate electrons and $\mathrm{CO}_{2}$. Note that succinate dehydrogenase constitutes complex II of the respiratory chain

$\Delta \psi_{\mathrm{m}}$ which on the other hand, is completely depolarised by the uncoupler carbonyl cyanide p-trifluoromethyl oxyphenyl-hydrazone (FCCP) (Fig.11). The succinate-induced hyperpolarisation explains the rise in mitochondrial $\mathrm{Ca}^{2+}[32,49,56]$. Succinate caused a pronounced biphasic stimulation of insulin secretion (Fig. 11). This stimulation was shown to depend on both the rise in mitochondrial $\mathrm{Ca}^{2+}$ and provision of carbons to the TCA cycle [32]. We can conclude from these and other experiments that increased succinate metabolism in the mitochondria leads to stimulation of the electron transport chain resulting in the hyperpolarisation of the $\Delta \psi_{\mathrm{m}}$. This drives $\mathrm{Ca}^{2+}$ uptake by the mitochondria. The mitochondrial $\mathrm{Ca}^{2+}$ increase acts in a feed-forward manner to stimulate the TCA cycle (Fig.9). This in turn generates a mitochondrial factor which activates the exocytotic release of insulin. The same sequence of events is seen in intact cells stimulated with glucose, i.e. hyperpolarisation of $\Delta \psi_{\mathrm{m}}$ and increased mitochondrial $\mathrm{Ca}^{2+}$ and TCA cycle-dependent generation of a coupling factor distinct from ATP [32, 48, 49, 56]. The mitochondrial factor was subsequently identified as glutamate [57].

\section{Role of mitochondrial DNA in insulin secretion}

It is thus clear that the respiratory chain is crucial for signal generation not only from succinate but also from glucose. The five enzyme complexes (CI to $\mathrm{CV}$ ) of the chain are localised on the cristae of the inner mitochondrial membrane and the electron flux 


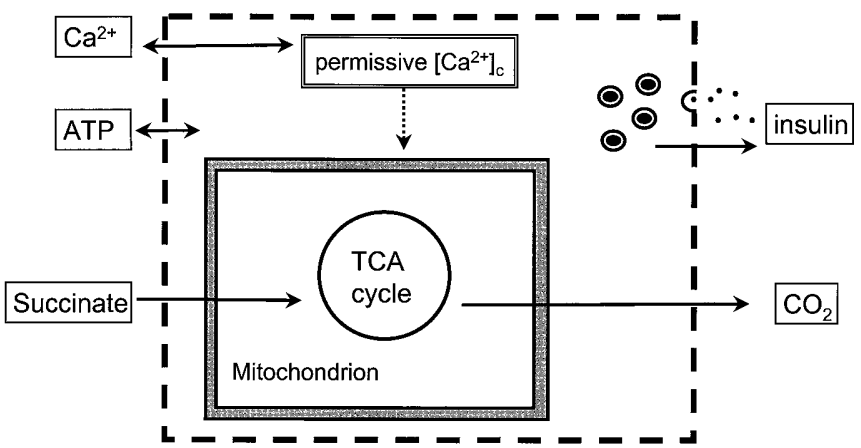

Fig. 10. Scheme of an insulin-secreting cell in which the plasma membrane has been premeabilised with Staphylococcus aureus $\alpha$-toxin. The pores allow the equilibration of the intracellular and extracellular spaces with respect to small solutes such as $\mathrm{Ca}^{2+}$, ATP and succinate

establishes a proton gradient across the inner membrane by extrusion of protons at complexes I, III and IV (Fig. 12). This proton gradient provides the energy for ATP synthesis from ADP and inorganic phosphate at complex V, the ATP synthase [10, 58]. Collapse of the proton gradient results in dissipation of the membrane potential (as elicited by FCCP) and blocks ATP synthesis [25]. The respiratory chain complexes are comprised of about one hundred polypeptide subunits of which 13 are encoded by the mitochondrial DNA, the remainder by the nuclear DNA. Nuclear DNA regulates the replication, transcription and translation of the mitochondrial DNA. This occurs through the import of proteins from the cytosol. Together the nuclear and the mitochondrial DNA accomplish the expression of the respiratory chain enzymes and normal oxidative phosphorylation [58-60]. Defects in oxidative metabolism lead to various disease phenotypes involving mainly organs of high energy need such as muscle, neurons and endocrine cells [58-61].

The first mitochondrial disease was described by Rolf Luft and associates in 1959 who reported a hypermetabolic syndrome in a patient with normal thyroid function [62, 63]. In 1992, linkage was described between mitochondrial DNA mutations and diabetes for both a deletion [64] and a point mutation [65]. The mitochondrial genome is a compact doublestranded DNA containing almost exclusively coding regions. In addition to the 13 polypeptides of the respiratory chain enzyme complexes, the mitochondrial DNA (mtDNA) encodes 22 transfer RNAs and two ribosomal RNAs [58-61]. A mutational hot spot seems to be the $t R N A^{\text {Leu(UUR) }}[61,66]$.

Mitochondrial diabetes accounts for approximately 1 to $2 \%$ of all cases of diabetes $[58,66]$. The disease is maternally inherited due to the transmission mode of mtDNA. The patients show progressive impairment of insulin secretion and the type 2 phenotype may eventually deteriorate to overt insulin depen-

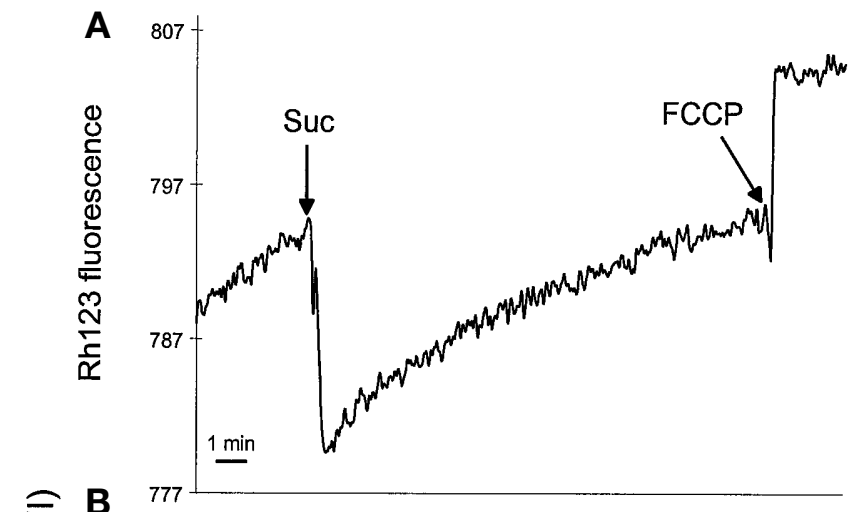

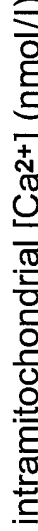
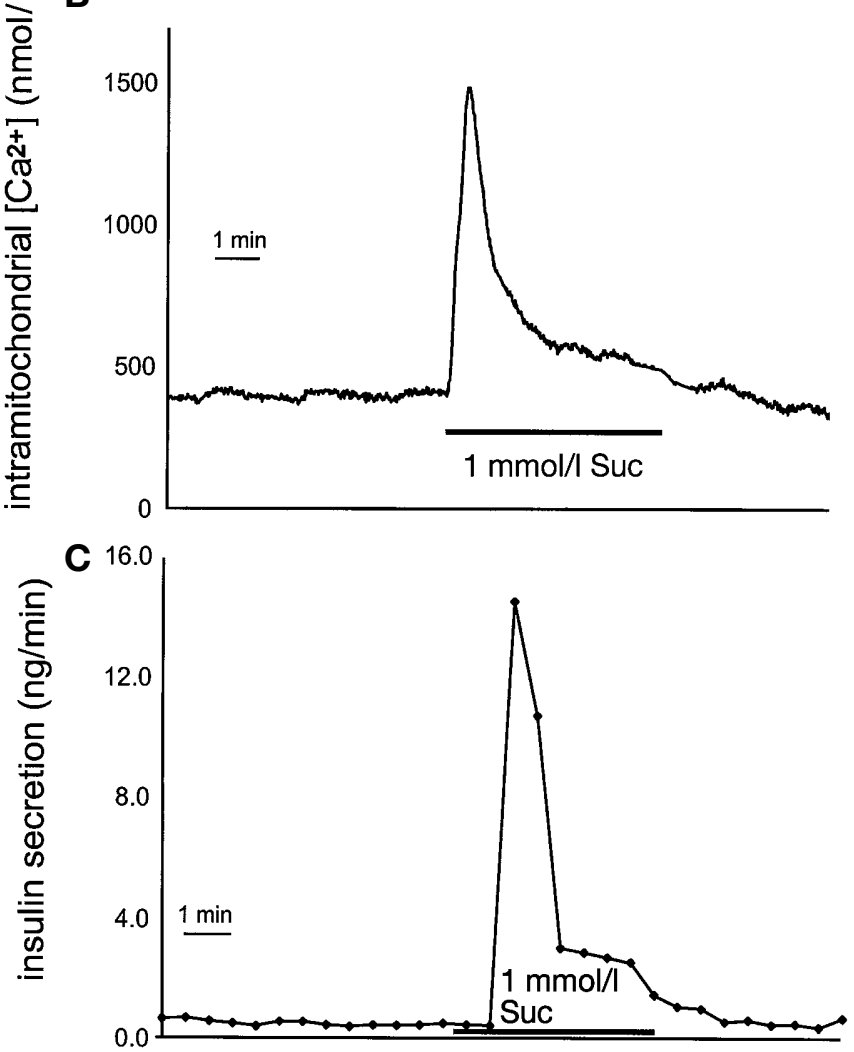

Fig.11A-C. Succinate hyperpolarises the mitochondrial membrane potential $(\mathbf{A})$, raises intramitochondrial $\mathrm{Ca}^{2+}(\mathbf{B})$ and stimulates insulin secretion $(\mathbf{C})$ in INS-1 cells permeabilised with Staphylococcus aureus $\alpha$-toxin. $\mathrm{Rh} 123$ = rhodamine 123. Modified and reprinted with permission from Maechler et al. [32]

dence. There is a frequent association with nerve deafness. The mitochondrial DNA mutations include deletions, substitutions and point mutations, e.g. in position bp3243 of $t R N A^{\operatorname{Leu}(U U R)}$. Patients with the mutation in position bp3243 in the $t R N A^{\operatorname{Leu}(U U R)}$ gene have impaired insulin secretion during an oral glucose tolerance test. The impairment was found to be most pronounced in diabetic patients also suffering from deafness [66]. To gain further insight into the function of the mitochondria that carry DNA mutations, clonal cell lines (cybrids) have been established which harbour these mitochondria [67]. Skin fi- 


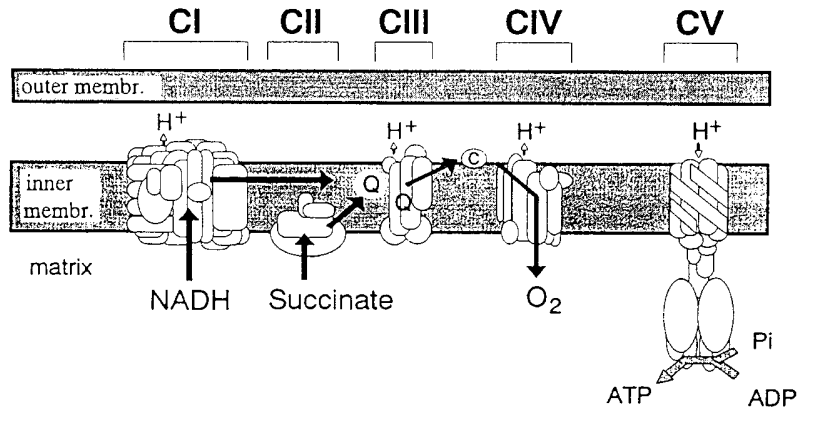

Fig.12. Scheme of the mitochondrial respiratory chain. The enzyme complexes CI to CV are located at the inner mitochondrial membrane and the flux of electrons along the chain establishes the proton gradient which generates the membrane potential (inside negative). $\rightarrow$ electron flux; $\rightarrow$ proton flux. Reprinted with permission from Rötig et al. [58]

Fig. 13. A Loss of glucose-stimulated insulin secretion in INS$1 \varrho^{0}$ cells (rho). B K ${ }^{+}$-stimulated insulin secretion is preserved in the $\varrho^{0}$ cells devoid of mitochondrial DNA. - INS-1; $-\bigcirc-$ INS-1 rho. Reprinted with permission from Kennedy et al. [26] broblasts, like all cells from patients with the 3243 point mutation in the $t R N A^{\operatorname{Leu}(U U R)}$, are heteroplasmic, that is, mutated and non-mutated mitochondrial DNA coexist within the same cell. In a patient with this mutation, $63 \%$ heteroplasmy of mtDNA was reported in beta cells, a value much higher than in the other tissues examined [68]. To enrich for mutated DNA, the skin fibroblasts were enucleated to yield cytoplasts containing the mitochondria. These cytoplasts were then fused with recipient cells, an osteosarcoma cell line, which had been depleted of mitochondrial DNA ( $\varrho^{0}$ cells $)$ by treatment with ethidium bromide [67]. This agent binds to DNA and because of the low repair capacity of mitochondrial DNA there is elimination of mitochondrial but not of nuclear DNA [69]. After fusion of patient cytoplasts with the recipient mitochondria-free $\varrho^{0}$ cells, cybrids were established. These were selected for clones with the highest degree of heteroplasmy, approaching $100 \%$ mutated mtDNA and were compared with cybrids containing $100 \%$ non-mutated (wild-type) mtDNA. The cell lines replenished with mutated mtDNA exhibit considerably reduced oxidative phosphorylation as reflected by reduced $\mathrm{O}_{2}$ consumption [67]. The mitochondria harbouring mutated mtDNA also present
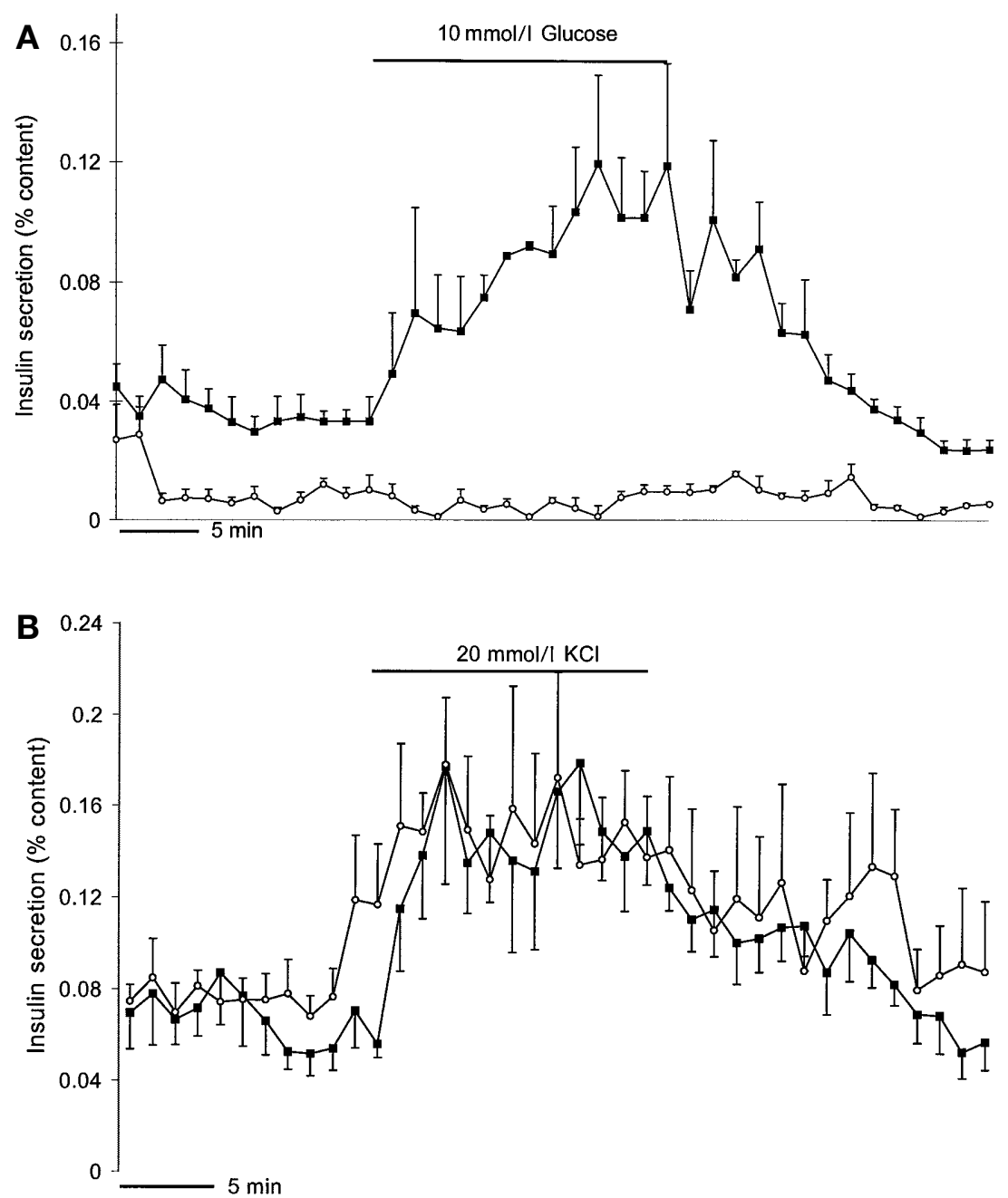


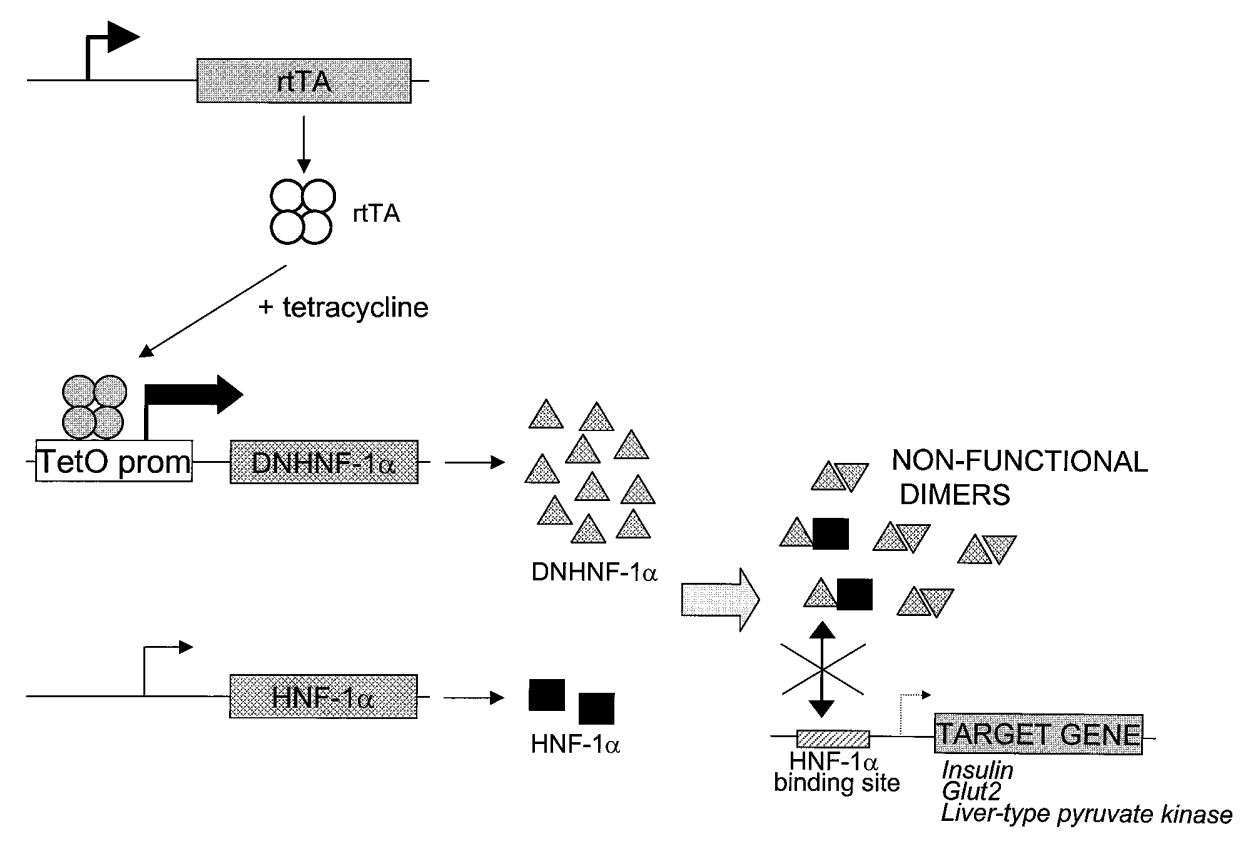

Fig. 14. Scheme for the controlled overexpression of a dominant-negative $H N F-1 \alpha$ mutant. INS-1 cells stably expressing the reverse tetracycline transactivator (rtTA) were transfected with the gene encoding dominant-negative $H N F-1 \alpha$ mutant placed under the control of the tetracycline operator (TetO). Tetracycline doxycycline produces dominant-negative HNF$1 \alpha(\triangle)$ which forms non-functional dimers with the endogenous, wild-type HNF-1 $\alpha$ (鲳). Thereby the transcription of HNF-1 $\alpha$ target genes is suppressed

altered morphology. When stained with the mitochondria dye Mito Tracker they are small and rounded, resembling those of the $\varrho^{0}$ cells. This contrasts with the normal mitochondria which have rod and filament-like shapes [67].

\section{Beta-cell model of mitochondrial diabetes}

The importance of intact mtDNA for normal insulin secretion can also be studied directly in insulin-secreting cells using a similar approach. Our group established mitochondrial DNA-deficient $\varrho^{0}$ INS-1 cells. Again, the mitochondria of the $\varrho^{0}$ cells were small and round, contrasting with the typical rod shape of the control cells. These $\varrho^{0}$ cells were indeed deficient in oxidative phosphorylation as shown by the absence of detectable cytochrome c oxidase activity. Furthermore, glucose failed to hyperpolarise $\Delta \psi_{\mathrm{m}}$ and did not increase ATP concentrations in INS-1 $\varrho^{0}$ cells [26]. Thus glycolysis alone is not sufficient to generate appropriate increases in ATP. Do INS- $1 \varrho^{0}$ cells secrete insulin? Glucose-stimulated insulin secretion was completely abolished in the $\varrho^{0}$ cells, whereas depolarisation with potassium, which raises cytosolic $\mathrm{Ca}^{2+}$ independent of cellular metabolism [48, 51], still evoked insulin secretion (Fig.13). Thus the chemical elimination of mitochondrial DNA leads to complete inhibition of glucose-stimulated insulin secretion [26]. Some experiments have, however, shown that formation of cybrids between enucleated donor cells containing normal mitochondria and $\varrho^{0}$ cells of the mouse beta-cell line MIN6 permitted restoration of glucose-induced insulin secretion [70]. These experiments thus unequivocally show the pivotal role of the mitochondria in glucose-stimulated insulin secretion.

\section{Maturity-onset diabetes of the young}

Maturity-onset diabetes of the young (MODY) is a monogenic, autosomal dominant, early onset form of Type II diabetes which was first described by Stefan Fajans in 1975 [71]. It could account for 2 to $5 \%$ of Type II diabetic patients [72]. In 1992 MODY2 was linked to mutations in glucokinase [73]. In 1996, the genes for MODY1 and MODY3 were identified, respectively as hepatocyte nuclear factor $4 \alpha(H N F-4 \alpha)$ [74] and $H N F-1 \alpha$ [75]. The MODY4 subform is also a transcription factor, namely $I P F-1 / I D X-1 / P D X-1 /$ $S T F-1 / I U F-1$ (a dear child bears many names!) [76]. Mutations in $I P F-1$ have very recently been suggested to confer susceptibility to late-onset Type II diabetes [77, 78]. The rare MODY5 subform has been linked to $H N F-1 \beta$ [79]. The genes for additional MODY sub-types are now being described [80]. The MODY2 subform is less severe [21] than the others $[74,75]$, many of which can eventually require insulin therapy [81, 82]. Except in MODY2, microvascular complications are generally present [81, 82]. In all cases, the pathophysiology involves beta-cell dysfunction. Patients with MODY3 barely respond to glucose with stimulation of insulin secretion, whereas 
Nutrient oxidation

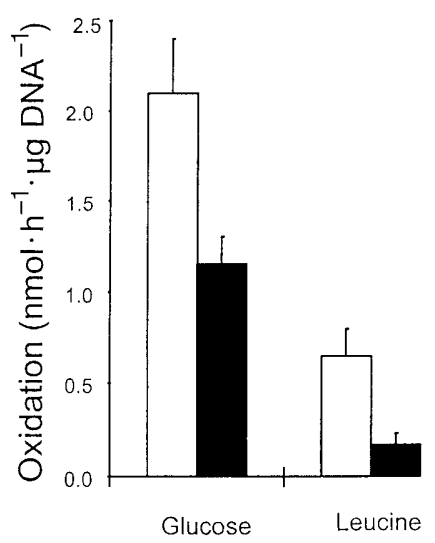

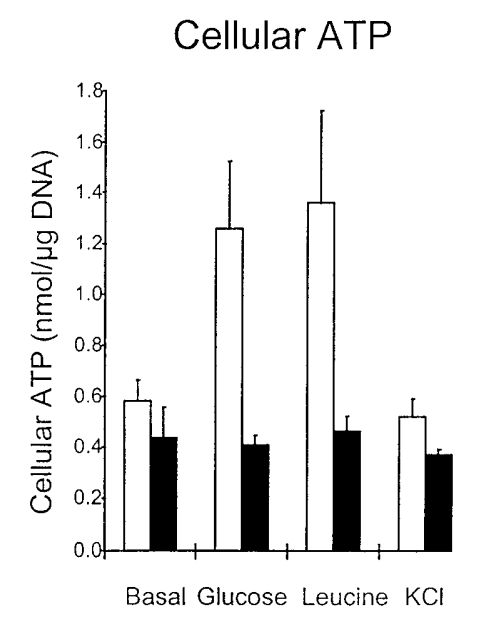

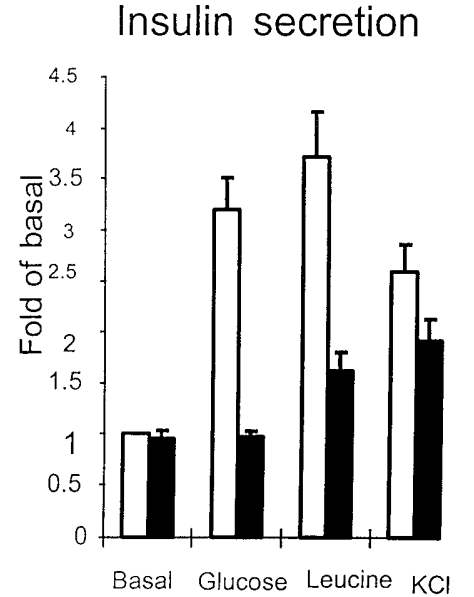

Fig. 15. Nutrient oxidation, ATP generation and insulin secretion are inhibited after induction of dominant-negative HNF$1 \alpha$ in INS- 1 cells. Mitochondrial oxidation was measured as $\mathrm{CO}_{2}$ production from ${ }^{14} \mathrm{C}$-labelled glucose and leucine. $\square$ Non-induced; ${ }^{-1}$ induced. Reprinted with permission from Wang et al. [85]

the marker-positive subjects without diabetes respond normally at intermediate glucose concentrations. Above $8 \mathrm{mmol} / \mathrm{l}$, they also, however, have considerable inhibition of insulin secretion during graded i.v. glucose infusions [83]. The MODY3/HNF-1 $\alpha$ gene comprises ten exons. Mutations have been described in the promoter region and in all exons [75, $81,82]$. The gene encodes a dimerisation domain at the N-terminus of the protein, a DNA-binding domain in the middle of the molecule and a C-terminal transactivation domain [81, 84]. Mutations can cause loss of function either by haploinsufficiency, that is, reduced gene dosage, or through a dominant-negative mechanism.

\section{Beta-cell model of MODY3}

Our group investigated the dominant-negative action of $H N F-1 \alpha$ mutations to examine the role of the transcription factor in gene expression and metabolism-secretion coupling in the beta cell [85]. Controlled overexpression of HNF-1 $\alpha$ mutations was achieved (Fig. 14). In a two-step procedure, the dominant-negative $H N F-1 \alpha$ was placed under the control of the reverse tetracycline transactivator. When such INS-1 cells are exposed to doxycycline, a tetracycline analogue, the increased binding of the reverse tetracycline transactivator promotes transcription of the dominant-negative $H N F-1 \alpha$. As this expression exceeds that of the endogenous wild-type HNF-1 $\alpha$, non-functional dimers are formed. Hepatic nuclear factor $1 \alpha$ can only activate transcription after dimerisation. Because the dominant-negative HNF-1 $\alpha$ mu- tants are devoid of DNA-binding capacity, the complexes can no longer attach to the HNF-1 $\alpha$ binding sites in the specific promoter regions of the target genes [84]. The transcription of insulin, of the glucose transporter GLUT 2 and of liver-type pyruvate kinase was suppressed in INS-1 cells after treatment with doxycycline [85].The induction of dominantnegative HNF-1 $\alpha$ also affects metabolism-secretion coupling.

Two days of induction of dominant-negative HNF$1 \alpha$ considerably reduced both glucose and leucine oxidation (Fig. 15). This was measured as the production of ${ }^{14} \mathrm{CO}_{2}$ from ${ }^{14} \mathrm{C}$-labelled nutrients. Similarly, ATP production during stimulation with either glucose or leucine was completely abolished. This was associated with suppressed glucose-stimulated insulin secretion. The effect evoked by leucine was also strongly inhibited. The cells still synthesised and stored insulin as potassium depolarisation-mediated secretion was much less affected (Fig. 15) [85].

We can surmise that HNF-1 $\alpha$ not only controls the expression of insulin and the glucose transporter GLUT 2 but also controls generation of metabolic coupling factors in the mitochondria (Fig.16). After suppression of HNF-1 $\alpha$ function TCA cycle activity is decreased, as reflected by reduced $\mathrm{CO}_{2}$ production from glucose and leucine. Consequently, the ATP production evoked by both glucose and leucine was abolished. This results in impaired membrane depolarisation and cytosolic $\mathrm{Ca}^{2+}$ rises elicited by the two nutrient secretagogues [85]. It has been observed that both glucose-stimulated insulin secretion and cytosolic $\mathrm{Ca}^{2+}$ rises are abrogated in islets from $H N F-1 \alpha$ knock-out mice [86]. These mice are diabetic but in contrast to MODY3 patients heterozygous mice are normoglycaemic. Although MODY is a monogenic disease, it can teach us many lessons for the better understanding of the more common forms of Type II diabetes. In particular, the role of transcription factors in the aetiology of the disease must be further investigated $[77,78]$. 


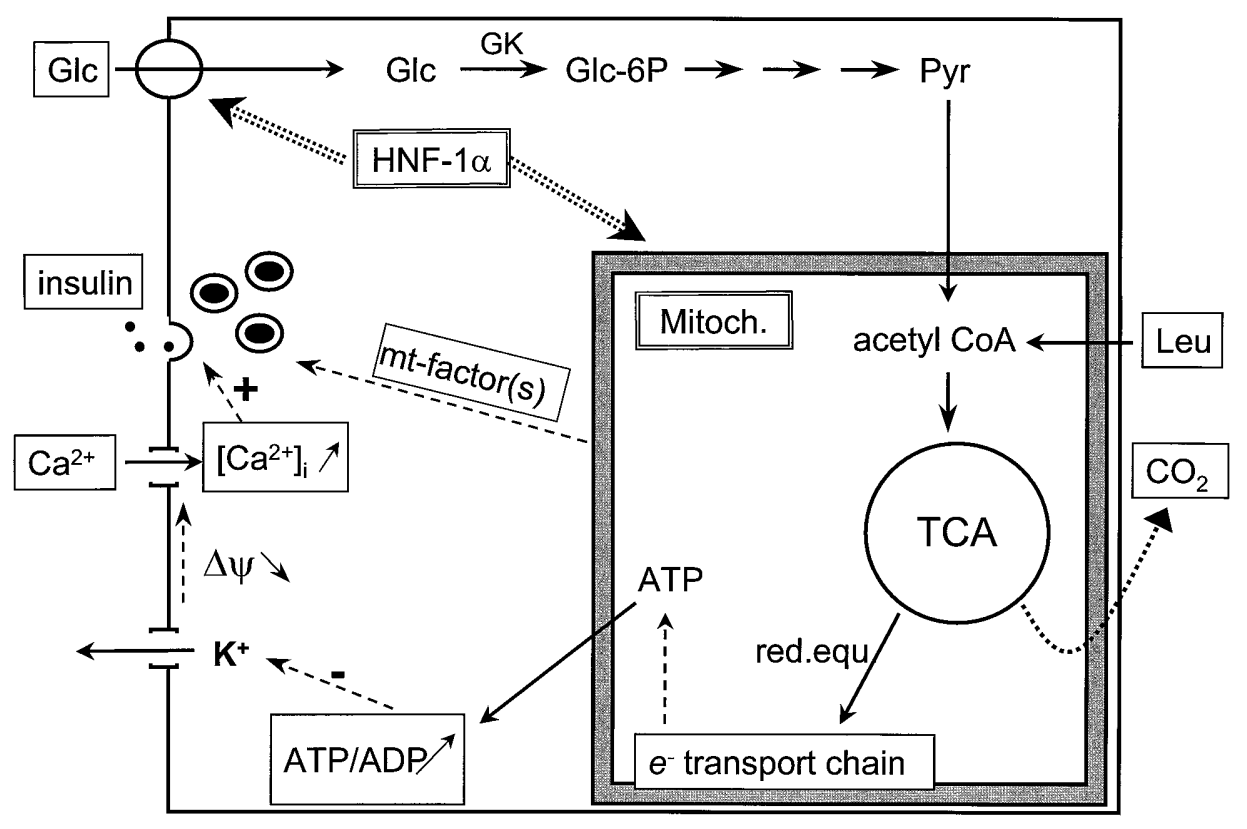

Fig. 16. Metabolism secretion coupling of nutrient-induced insulin release is controlled at multiple sites by the transcription factor HNF-1 $\alpha$. Dominant-negative HNF-1 $\alpha$ suppresses GLUT 2 at the plasma membrane and lowers mitochondrial metabolism of both glucose and leucine. This reduces the generation of ATP and other mitochondrial factors required for the increase in cytosolic $\mathrm{Ca}^{2+}$ and the exocytosis of insulin

\section{Conclusion}

One of Claude Bernard's principles for medical science was the importance of the close relation between the clinic and the research laboratory. This concept is of high actuality in diabetes research where the description of specific clinical phenotypes has led to the discovery of the MODY diabetes genes. The impact of mutations in these genes on beta-cell function will most certainly help to clarify the role of the mitochondria in the common polygenic form of Type II diabetes. This should be achieved through identification of new target genes for HNF-1 $\alpha$ and the other transcription factors which have been linked to the monogenic MODY syndromes. Further clinical studies with leucine and other insulin secretagogues of known mitochondrial action should help explain the proposed dysfunction of mitochondrial signal generation in the beta cell of the Type II diabetic patient. The definition of new metabolic coupling factors of mitochondrial origin [57] will also further our understanding of clinical conditions with impaired insulin secretion or with hyperinsulinism [87].

Acknowledgements. I am greatly indebted to the European Association for the Study of Diabetes and to the Paul Neuman Foundation for the honour of having been selected as 1998 Claude Bernard lecturer. I should like to reiterate my gratitude to my mentor, the late Professor Albert Renold, who not only introduced me to diabetes research but also supported and encouraged me for the first sixteen years of my academic career. I would also like to mention two other mentors, Professor G. Sharp of Cornell University and Professor T. Pozzan of the University of Padua who introduced me to various aspects of biochemistry and cell biology. I am also grateful to Professor L. Orci of the University of Geneva. It is impossible to enumerate all collaborators over the years who have contributed to the concepts presented in this lecture but I am particularly grateful to my present collaborators Dr P. Meachler, Dr J. Lang, Dr H. Wang, Ms K. Hagenfeldt, Dr H. Ishihara and Dr P. Antinozzi. I am particularly indebted to Ms J. Gunn for invaluable help in the screening of the literature and the preparation of manuscripts.

The support to my research by the Swiss National Science Foundation is gratefully acknowledged.

\section{References}

1. Renold AE, Rabinovitch A, Wollheim CB et al. (1974) Spontaneous and experimental diabetic syndromes in animals. A re-evaluation of their usefulness for approaching the physio-pathology of diabetes. (Claude Bernard Lecture 1973) In: WJ Malaisse, J Pirart (eds) Diabetes. Excerpta Medica Internat. Congress Series 312: 22-38, Amsterdam

2. Bernard C (1859) Leçons sur les propriétés physiologiques et les altérations pathologiques des liquides de l'organisme. J.B. Baillere et fils, Paris

3. Bernard C (1849) Du suc pancréatique et de son rôle dans les phénomènes de la digestion. Mémoires de la Société de Biologie 1: 99-115

4. Orci L (1974) A portrait of the pancreatic $\beta$-cell (Minkowski Lecture 1973). Diabetologia 10: 163-187

5. Wollheim CB, Lang J, Regazzi R (1996) The exocytotic process of insulin secretion and its regulation by $\mathrm{Ca}^{2+}$ and G-proteins. Diabetes Rev 4: 276-297

6. Lang J (1999) Molecular mechanisms and regulation of insulin exocytosis as a paradigm of endocrine secretion. Eur J Biochem 259: 3-17

7. Sharp GWG (1996) Mechanisms of inhibition of insulin release. Am J Physiol 271: C1781-C1799 
8. Rorsman P (1997) The pancreatic beta-cell as a fuel sensor: an electrophysiologist's viewpoint (Minkowski Lecture 1996). Diabetologia 40: 487-495

9. Bock JB, Scheller RH (1999) SNARE proteins mediate lipid bilayer fusion. Proc Natl Acad Sci USA 96: 12227-12229

10. Voet D, Voet JG (1995) Biochemistry, 2nd edn. John Wiley \& Sons, New York

11. Cerasi E (1975) Mechanisms of glucose stimulated insulin secretion in health and in diabetes: some re-evaluations and proposals (Minkowski Lecture 1974). Diabetologia 11: $1-13$

12. Porte D Jr (1991) $\beta$-cells in type II diabetes mellitus (Banting Lecture 1990). Diabetes 40: 166-180

13. Hosker JP, Rudenski AS, Burnett MA, Matthews DR, Turner RC (1989) Similar reduction of first-and secondphase $\beta$-cell responses at three different glucose levels in type II diabetes and the effect of gliclazide therapy. Metabolism 38: 767-772

14. DeFronzo RA (1997) Pathogenesis of type 2 diabetes: metabolic and molecular implications for identifying diabetes genes. Diabetes Rev 5: 177-269

15. Vaag A, Henriksen JE, Madsbad S, Holm N, Beck-Nielsen $\mathrm{H}$ (1995) Insulin secretion, insulin action, and hepatic glucose production in identical twins discordant for non-insulin-dependent diabetes mellitus. J Clin Invest 95: 690-698

16. Pimenta W, Korytkowski M, Mitrakou A et al. (1995) Pancreatic $\beta$-cell dysfunction as the primary genetic lesion in NIDDM. JAMA 273: 1855-1861

17. Newgard CB, McGarry JD (1995) Metabolic coupling factors in pancreatic $\beta$-cell signal transduction. Annu Rev Biochem 64: 689-719

18. Matschinsky FM (1996) A lesson in metabolic regulation inspired by the glucokinase glucose sensor paradigm (Banting Lecture 1995). Diabetes 45: 223-241

19. De Vos A, Heimberg H, Quartier E et al. (1995) Human and rat beta cells differ in glucose transporter but not in glucokinase gene expression. J Clin Invest 96: 2489-2495

20. Iynedjian PB (1993) Mammalian glucokinase and its gene. Biochem J 293: 1-13

21. Froguel P, Zouali H, Vionnet N at al. (1993) Familial hyperglycemia due to mutations in glucokinase: definition of a subtype of diabetes mellitus. N Engl J Med 328: 697-702

22. Schuit F, De Vos A, Farfari S (1997) Metabolic fate of glucose in purified islet cells. J Biol Chem 272: 18572-18579

23. Sekine N, Cirulli V, Regazzi R et al. (1994) Low lactate dehydrogenase and high mitochondrial glycerol phosphate dehydrogenase in pancreatic $\beta$-cell. Potential role in nutrient sensing. J Biol Chem 269: 4895-4902

24. Ishihara H, Wang H, Drewes LR, Wollheim CB (1999) Overexpression of monocarboxylate transporter and lactate dehydrogenase alters insulin secretory responses to pyruvate and lactate in $\beta$ cells. J Clin Invest 104: 1621-1629

25. Maechler P, Wang H, Wollheim CB (1998) Continuous monitoring of ATP levels in living insulin secreting cells expressing cytosolic firefly luciferase. FEBS Lett 422: 328-332

26. Kennedy ED, Maechler P, Wollheim CB (1998) Effects of depletion of mitochondrial DNA on metabolism-secretion coupling in INS-1 cells. Diabetes 47: 374-380

27. Eto K, Tsubamoto Y, Terauchi Y et al. (1999) Role of $\mathrm{NADH}$ shuttling system in glucose-induced activation of mitochondrial metabolism and insulin secretion. Science 283: 981-985

28. Wollheim CB, Sharp GW (1981) Regulation of insulin release by calcium. Physiol Rev 61: 914-973

29. Pralong WF, Bartley C, Wollheim CB (1990) Single islet $\beta$ cell stimulation by nutrients: relationship between pyri- dine nucleotides, cytosolic $\mathrm{Ca}^{2+}$ and secretion. EMBO J 9: 53-60

30. Duchen MR, Smith PA, Ashcroft FM (1993) Substrate-dependent changes in mitochondrial function, intracellular free calcium concentration and membrane channels in pancreatic $\beta$-cells. Biochem J 294: 35-42

31. Pralong WF, Spät A, Wollheim CB (1994) Dynamic pacing of cell metabolism by intracellular $\mathrm{Ca}^{2+}$ transients. J Biol Chem 269: 27310-27314

32. Maechler P, Kennedy ED, Pozzan T, Wollheim CB (1997) Mitochondrial activation directly triggers the exocytosis of insulin in permeabilized pancreatic $\beta$-cells. EMBO J 16: 3833-3841

33. Detimary P, Dejonghe S, Ling Z, Pipeleers D, Schuit F, Henquin J-C (1998) The changes in adenine nucleotides measured in glucose-stimulated rodent islets occur in $\beta$ cells but not in $\alpha$ cells and are also observed in human islets. J Biol Chem 273: 33905-33908

34. Cook DL, Hales CN (1984) Intracellular ATP directly blocks $\mathrm{K}$ channels in pancreatic $\beta$-cells. Nature 211: 269-271

35. Ashcroft FM, Harrison DE, Ashcroft SJH (1984) Glucose induces closure of single potassium channels in isolated rat pancreatic $\beta$-cells. Nature 312: 446-448

36. Dean PM, Matthews EK (1968) Electrical activity in pancreatic islet cells. Nature 219: 389-390

37. Horváth A, Szabadkai G, Vámai P et al. (1998) Voltage dependent calcium channels in adrenal glomerulosa cells and in insulin producing cells. Cell Calcium 23: 33-42

38. Ligon B, Boyd AE 3rd, Dunlap K (1998) Class A calcium channel variants in pancreatic islets and their role in insulin secretion. J Biol Chem 273: 13905-13911

39. Rorsman P (1997) The pancreatic beta-cell as a fuel sensor: an electrophysiologist's viewpoint (Minkowski Lecture 1996). Diabetologia 40: 487-495

40. McCormack JG, Halestrap AP, Denton RM (1990) Role of calcium ions in regulation of mammalian intramitochondrial metabolism. Physiol Rev 70: 391-425

41. Prentki M (1996) New insights into pancreatic beta-cell metabolic signaling in insulin secretion. Eur $\mathbf{J}$ Endocrinol 134: 272-286

42. Bratusch-Marrain P, Ferenci P, Waldhäusl W (1980) Leucine assimilation in patients with diabetes mellitus. Acta Endocrinol 93: 461-465

43. Smith PA, Sakura H, Coles B, Gummerson N, Proks P, Ashcroft FM (1997) Electrogenic arginine transport mediates stimulus-secretion coupling in mouse pancreatic $\beta$ cells. J Physiol 499: 625-635

44. Inagaki N, Gonoi T, Clement JP 4th et al. (1995) Reconstitution of $/_{\text {KATP }}$ an inward rectifier subunit plus the sulfonylurea receptor. Science 270: 1166-1170

45. Hellman B (1985) $\beta$-cell cytoplasmic $\mathrm{Ca}^{2+}$ balance as a determinant for glucose-stimulated insulin release. Diabetologia 28: 494-501

46. Malaisse WJ (1996) Metabolic signaling of insulin secretion. Diabetes Rev 4: 145-159

47. Asfari M, Janjic D, Meda P, Li G, Halban PA, Wollheim CB (1992) Establishment of 2-mercaptoethanol dependent differentiated insulin secreting cell lines. Endocrinology 130: $167-178$

48. Kennedy ED, Rizzuto R, Thaler J-M et al. (1996) Glucosestimulated insulin secretion correlates with changes in mitochondrial and cytosolic $\mathrm{Ca}^{2+}$ in aequorin expressing INS-1 cells. J Clin Invest 98: 2524-2538

49. Kennedy ED, Wollheim CB (1998) Role of mitochondrial calcium in metabolism-secretion coupling in nutrient-stimulated insulin release. Diabetes Metab 24: 15-24 
50. Gembal M, Gilon P, Henquin JC (1992) Evidence that glucose can control insulin release independently from its action on ATP-sensitive $\mathrm{K}^{+}$channels in mouse $\beta$-cells. J Clin Invest 89: 1288-1295

51. Henquin JC, Gembal M, Detimary P, Gao ZY, Warnotte C, Gilon P (1994) Multisite control of insulin release by glucose. Diabète Metab 20: 132-137

52. Sato Y, Aizawa T, Komatsu M, Okada N, Yamada T (1992) Dual functional role of membrane depolarization $/ \mathrm{Ca}^{2+}$ influx in rat pancreatic $\beta$-cell. Diabetes 41: 438-443

53. Hansford RG (1991) Dehydrogenase activation by $\mathrm{Ca}^{2+}$ in cells and tissues. J Bioenerg Biomembr 23: 823-854

54. Sener A, Rasschaert J, Malaisse WJ (1990) Hexose metabolism in pancreatic islets. Participation of $\mathrm{Ca}^{2+}$-sensitive 2ketoglutarate dehydrogenase in the regulation of mitochondrial function. Biochim Biophys Acta 1019: 42-50

55. Civelek VN, Deeney JT, Shalosky NJ et al. (1996) Regulation of pancreatic $\beta$-cell mitochondrial metabolism: influence of $\mathrm{Ca}^{2+}$, substrate and ADP. Biochem J 318: 615-621

56. Maechler P, Kennedy ED, Wang H, Wollheim CB (1998) Desensitization of mitochondrial $\mathrm{Ca}^{2+}$ and insulin secretion responses in the $\beta$-cell. J Biol Chem 273: 20770-20778

57. Maechler P, Wollheim CB (1999) Mitochondrial glutamate acts as a messenger in glucose-induced insulin exocytosis. Nature 402: 685-689

58. Rötig A, Bonnefont J-P, Munnich A (1996) Mitochondrial diabetes mellitus. Diabetes Metab 22: 291-298

59. Wallace DC (1992) Diseases of the mitochondrial DNA. Annu Rev Biochem 61: 1175-1212

60. Johns DR (1995) Mitochondrial DNA and disease. N Engl J Med 333: 638-644

61. Sherratt EJ, Thomas AW, Alcolado JC (1997) Mitochondrial DNA defects: a widening clinical spectrum of disorders. Clin Sci 92: 225-235

62. Ernster L, Ikkos D, Luft R (1959) Enzymic activities of human skeletal muscle mitochondria: a tool in clinical metabolic research. Nature 184: 1851-1854

63. Luft R, Ikkos D, Palmieri G, Ernster L, Afzelius B (1962) A case of severe hypermetabolism of nonthyroid origin with a defect in the maintenance of mitochondrial respiratory control: a correlated clinical, biochemical and morphological study. J Clin Invest 41: 1776-1804

64. Ballinger SW, Shoffner JM, Hedaya EV et al. (1992) Maternally transmitted diabetes and deafness associated with a $10.4 \mathrm{~kb}$ mitochondrial DNA deletion. Nat Genet 1: 11-15

65. Van den Ouweland JMW, Lemkes HHPJ, Ruitenbeck W et al. (1992) Mutation in mitochondrial tRNA Leu(UUR) $^{\text {Lech }}$ gene in a large pedigree with maternally transmitted type II diabetes mellitus and deafness. Nat Genet 1: 368-371

66. Gerbitz K-D, Van den Ouweland JMW, Maassen JA, Jaksch M (1995) Mitochondrial diabetes mellitus: a review. Biochim Biophys Acta 1271: 253-260

67. Van den Ouweland JMW, Maechler P, Wollheim CB, Attardi G, Maassen JA (1999) Functional and morphological abnormalities of mitochondria harbouring the tRNA ${ }^{\text {Leu(UUR) }}$ mutation in mitochondrial DNA derived from patients with maternally inherited diabetes and deafness (MIDD) and progressive kidney disease. Diabetologia 42: 485-492

68. Kobayashi T, Nakanishi K, Nakase H et al. (1997) In situ characterization of islets in diabetes with a mitochondrial DNA mutation at nucleotide position 3243. Diabetes 46: 1567-1671

69. King MP, Attardi G (1989) Human cells lacking mtDNA repopulation with exogenous mitochondria by complementation. Science 246: 500-503
70. Soejima A, Inoue K, Takai D et al. (1996) Mitochondrial DNA is required for regulation of glucose-stimulated insulin secretion in a mouse pancreatic $\beta$-cell line MIN6. J Biol Chem 271: 26194-26199

71. Tattersall RB, Fajans SS (1975) A difference between the inheritance of classical juvenile-onset and maturity-onset type diabetes of young people. Diabetes 24: 44-53

72. Fajans SS, Bell GI, Bowden DW, Halter JB, Polonsky KS (1994) Maturity-onset diabetes of the young. Life Sci 55: 413-422

73. Froguel Ph, Vaxillaire M, Sun F et al. (1992) Close linkage of glucokinase locus on chromosome $7 p$ to early-onset non-insulin-dependent diabetes mellitus. Nature 356: 162-164

74. Yamagata K, Furuta H, Oda N et al. (1996) Mutations in the hepatocyte nuclear factor- $4 \alpha$ gene in maturity-onset diabetes of the young. Nature 384: 458-460

75. Yamagata K, Oda N, Kaisaki PJ et al. (1996) Mutations in the hepatocyte nuclear factor- $1 \alpha$ gene in maturity-onset diabetes of the young. Nature 384: 455-458

76. Stoffers DA, Ferre J, Clarke WL, Habener JF (1997) Early-onset type-II diabetes mellitus (MODY 4) linked to IPF-1. Nat Genet 17: 138-139

77. Macfarlane WM, Frayling TM, Ellard S et al. (1999) Missense mutations in the insulin promoter factor-1 gene predispose to type 2 diabetes. J Clin Invest 104: R33-R39

78. Hani EH, Stoffers DA, Chèvre J-C et al. (1999) Defective mutations in the insulin promoter factor-1 (IPF-1) gene in late-onset type 2 diabetes mellitus. J Clin Invest 104: R41-R48

79. Lindner T, Yamagata K, Ogata M et al. (1997) Mutation in hepatocyte nuclear factor-1 $\beta$ gene (TCF2) associated with MODY. Nat Genet 17: 384-385

80. Malecki MT, Jhala US, Antonellis A et al. (1999) Mutations in NEUROD1 are associated with the development of type 2 diabetes mellitus. Nat Genet 23: 323-328

81. Hattersley AT (1998) Maturity-onset diabetes of the young: clinical heterogeneity explained by genetic heterogeneity. Diabet Med 15: 15-24

82. Velho G, Froguel Ph (1998) Genetic, metabolic and clinical characteristics of maturity onset diabetes of the young. Eur J Endocrinol 138: 233-239

83. Byrne MM, Sturis J, Menzel S et al. (1996) Altered insulin secretory responses to glucose in diabetic and nondiabetic subjects with mutations in the diabetes susceptibility gene MODY3 on chromosome 12. Diabetes 45: 1503-1510

84. Nicosia A, Monaci P, Tomei L et al. (1990) A myosin-like dimerization helix and an extra-large homeodomain are essential elements of the tripartite DNA binding structure of LFB1. Cell 6: 1225-1236

85. Wang H, Maechler P, Hagenfeldt KA, Wollheim CB (1998) Dominant-negative suppression of HNF-1 $\alpha$ function results in defective insulin gene transcription and impaired metabolism-secretion coupling in a pancreatic $\beta$-cell line. EMBO J 17: 6701-6713

86. Pontoglio M, Sreenan S, Roe M et al. (1998) Defective insulin secretion in hepatocyte factor $1 \alpha$-deficient mice. $\mathrm{J}$ Clin Invest 101: 2215-2222

87. Stanley CA, Lieu YK, Hsu BY et al. (1998) Hyperinsulinism and hyperammonemia in infants with regulatory mutations of the glutamate dehydrogenase gene. N Engl J Med 338: $1352-1357$ 